\title{
Utanför den svarta lådan: Ett utvecklingsarbete om medie- och informationskunnighet i lärarutbildningen på Södertörns högskola
}

\author{
Michael Forsman*, Ingrid Forsler och Jenny Magnusson \\ Södertörns högskola, Sweden
}

\begin{abstract}
Landets lärarutbildningar har problem med att förbereda framtidens lärare för den alltmer digitaliserade skolan. Digital kompetens är redan en integrerad del i skolornas verksamhet men lärarstudenter, skolor, lärarfack, politiker, teknikföretag och andra pekar på att landets lärarutbildningar släpar efter. Vår uppkopplade samtid behöver också satsningar på medie- och informationskunnighet (MIK). I den här artikeln beskriver och reflekterar tre lärarutbildare från Södertörns högskola över sitt arbete med MIK som inom ramen för en pågående satsning i lärarutbildningen används som samlingsterm för tre förmågor som både lärarstudenter och lärarutbildare bör nå: digital kompetens, mediekunnighet och informationskunnighet. Målsättningen med att implementera dessa tre förmågor och begrepp på lärarutbildningen har varit att kombinera konkret tillämpning och kritisk reflektion för att på så sätt skapa förutsättningar för att utbilda medie- och teknikmedvetna lärare för den digitaliserade skolan och det medialiserade sambället. I artikeln diskuteras organisatoriska och praktiska utmaningar med ett sådant utvecklingsarbete samt vikten av samverkan, erfarenhetsutbyte och kontinuitet. En slutsats är att det är viktigt att tänka på digitala medier inte bara i termer av verktyg utan också som miljöer inom vilka lärarutbildningen ska utbilda digitalt kompetenta lärare för framtiden och samtidigt behålla sin autonomi visavi starka externa ekonomiska, politiska och pedagogiska krafter.
\end{abstract}

Nyckelord: lärarutbildning, digitalisering, medie- och informatonskunnighet (MIK), digital kompetens, utbildningsteknologi, medieinfrastruktur, utvecklingsarbete, progression

\section{INLEDNING}

Landets lärarutbildningar har länge strävat efter att förbereda framtidens lärare för den alltmer digitaliserade skolan och mötet med elevernas medialiserade uppväxt. Behovet har accentuerats av att digital kompetens har knutits till läroplanen (Skolverket, 20I8) och av pågående diskussioner om vikten av medie- och informationskunnighet (MIK) (jfr Carlsson, 20I8). Samtidigt visar en färsk studie från Statens medieråd (2019) att kunskaperna är fortsatt begränsade inom landets lärarutbildningar. Härmed öppnas en rad frågor gällande hur landets lärarutbildningar ska hantera det som tycks vara ett medialt skifte också för skolans del. Förutom att utveckla förmågan att planera och genomföra lektioner med hjälp av digitala verktyg, medier och system (vilket i sig är en stor utmaning) bör lärarutbildningar också utbilda reflekterande praktiker som kan fatta kloka beslut i fråga om olika digitala lösningar. I detta ingår att de bör ha en viss historisk och kritisk förståelse för digitalisering som samhällsomvandlingsprocess, insikter om det inflytande som globala plattformsföretag har samt förmåga att reflektera kring automatiserat

*Författarkontakt: michael.forsman@sh.se 
lärande, robotisering, AI i skolan och utvecklandet av "smarta skolor". Dessa områden påverkas i sin tur av mer övergripande teknikutveckling och samhällsomvandling.

I den här artikeln beskriver vi ett pågående förändringsarbete inom lärarutbildningen vid Södertörns högskola där vi har använt MIK som paraplybegrepp i arbetet med att utforma program- och kursinnehåll för den medie- och teknikmedvetna läraren $i$ den digitaliserade skolan och det medialiserade sambället. Detta arbete har delats in i tre orienteringar: digital kompetens, mediekunnighet och informationskunnighet. Vi kommer att återkomma till dessa begrepp längre fram i artikeln. Artikeln är inte tänkt att fungera som ett teoretiskt eller begreppsutredande bidrag, eller som en didaktiskt orienterad och avgränsad studie som utröner fördelar och nackdelar med digitalisering inom lärarutbildning. Det vi vill beskriva och diskutera är snarare en arbets- och implementeringsprocess vid Södertörns högskola, med nya teman och arbetsformer som kan kopplas till skolans digitalisering och samhällets medialisering.

Dessa diskussioner är inte något nytt inom lärarutbildningen på Södertörns högskola men begreppsanvändning och frågor om ansvar för implementering, kontinuitet och samspel mellan olika kurser och lärarprogram har ofta varit oklara. MIK-kompetens finns på flera håll inom högskolan men det har varit svårt att få överblick över denna kompetens för att planera och samordna undervisning med koppling till MIK. Det var i ljuset av detta några frågor, som också denna artikel förhåller sig till, formulerades:

- Hur kan ett långsiktigt arbete med MIK organiseras på lärarutbildningen?

- På vilka sätt kan implementering och integration av MIK i olika kurser och lärarprogram genomföras?

- Hur kan MIK begreppsliggöras för att fånga komplexiteten i ämnesområdet och möjliggöra kritiska och historiserande perspektiv på skolans digitalisering?

I fokus står lärarutbildningen vid Södertörns högskola och arbete med MIK som på olika sätt har pågått sedan 20I4, men som först under de senaste åren systematiserats och organiserats på ett tydligt sätt. Arbetet som beskrivs här är inspirerat av Grönlunds (20I4) samt Grönlunds och Wiklunds (20I8) forskning om hur digitalisering kan förändra skolors verksamhet. I detta betonas vikten av långsiktighet och vikten av att inte lägga in ny teknologi i gamla processer. Istället bör fokus ligga på förändring i kursupplägg och undervisningsformer, vilket är en utmaning vid varje lärosäte. Arbetet vid Södertörns högskola har än så länge bara påbörjats, och vår förhoppning är att denna artikel kan inspirera andra och verka som en inbjudan till gemensam dialog mellan landets lärarutbildningar kring dessa aktuella och angelägna frågor.

Vi hävdar att skolans och lärarutbildningens digitalisering inte enkom bör förstås i termer av digitala verktyg utan kanske snarare ses som ett pågående miljöskifte. I och med detta öppnas frågor kring vad vi framöver kommer att mena med begrepp som skola, lärare, undervisning och lärande. Mer konkret vill vi peka på att det utifrån befintliga upplägg och med relativt enkla medel går att komma igång med ett förändringsarbete, samtidigt som vi reflekterar över vissa organisatoriska och praktiska utmaningar i detta.

\section{NÅGRA INGÅNGSVÄRDEN}

Skolan skapades i anknytning till "den typografiska människan" (McLuhan, 1969). Nu är den på väg in i digitala system för artificiell intelligens (AI) och gränslös datafiering med vad man kan förstå som "den elektroniska och mätbara människan" i centrum. Med andra ord väntar svåra men intressanta utmaningar för framtidens lärare när de ska använda digitala verktyg, medier 


\section{Michael Forsman, Ingrid Forsler \& Jenny Magnusson}

och system för att bedriva undervisning på ett modernt, effektivt och läroplansriktigt sätt. En konkret fråga är hur dessa kompetenser kan knytas till kursplaner och andra styrdokument. På ett mer övergripande plan aktualiseras också frågor kring hur man kan skapa en djupare förståelse och ett gott omdöme i förhållande till skolans digitala miljö, samt hur blivande lärare och lärarutbildare ska förhålla sig till de starka påverkanskrafter och affärsintressen som redan nu är en integrerad del av det vi kallar allmän skola (van Dijck, Poell \& Waal, 20I8; Williamson, 20I7).

Begreppet digitalisering bör här kommenteras. I grunden står det för en teknisk skillnad och övergång mellan analog och digital information (digitization), ett skifte som i många sammanhang redan är genomfört. Den andra dimensionen av digitaliseringsbegreppet handlar om en genomgripande och generell samhällsomvandling (digitalization), och det är i denna bredare betydelse som begreppet används i denna artikel. Andra men parallella utmaningar för lärarutbildningen ges av den fördjupade medialiseringen av samhället. Medialisering syftar på att medieinstitutioner, medieteknologier och medielogiker på ett djupt och genomgripande sätt genomsyrar och betingar samhällets institutioner och vardagslivsformer (Krotz, 20I4). Således ska medialisering skiljas från mediering (i betydelsen faktisk överföring, kommunikation).

Både digitalisering och medialisering har en djup inverkan på organisation, praktiker och roller inom skolans område (Breiter, 20I4). Bägge begreppen är systemorienterade och historiserande (jfr globalisering, urbanisering) och pekar på universella, differentierade, irreversibla förändringar i sociala relationer och praktiker inom system- och livsvärld. Poängen med att använda den här typen av perspektiv är att komma ifrån den presentism och instrumentalism som lätt karakteriserar diskussioner om skolans digitalisering för att istället eftersträva ett holistiskt och historiserande perspektiv. Detta knyter an till ett medieekologiskt och mediumteoretiskt tänkande om undervisningsteknologier och mediebruk i skolan (jfr Erixon, 20I4; McLuhan, 1987; Postman, 1992) och tankar om medier som miljöer och infrastrukturer som utgör förutsättningen för all skolverksamhet (jfr Forsler, 2020; Forsman, 2018).

Skolans digitalisering har pågått i flera decennier och kantats av flera stora satsningar på att implementera hårdvaror, system, fortbildning (Hylén, 20II). Under de senaste tio åren har utvecklingen gått in i en ny fas med övergångar till en-till-en-system (en dator/lärplatta per elev och lärare), lärplattformar samt uppkopplade skolor och klassrum. Till detta kommer de tilllägg som Skolverket $(2017,2018)$ relativt nyligen har gjort gällande digital kompetens i läroplanen. Enligt den expansiva branschen för utbildningsteknologi (ed-tech) är nästa steg i skolans digitalisering övergång till "smarta skolor" och ett mer personaliserat lärande (Selwyn, 2016; Williamson, 20I7). Därmed kan verksamheten bedrivas på ett snabbare och effektivare sätt samtidigt som lärandet blir mer mätbart och möjligt att styra och påverka. Förespråkarna menar att detta ger en mer demokratisk och inkluderande skola i och med att undervisningen anpassas till varje barns förutsättningar och behov, samtidigt som det bidrar till att göra skolan och undervisningen mer lustfylld och engagerande. Enligt andra tilltar övervakningen och synen på kunskap styrs av vad som är möjligt att mäta (Biesta, 20II; Jarke \& Breiter, 20I9).

Svensk forskning gällande digitaliseringens effekter på lärandet pekar i olika riktningar. Vissa studier lyfter fram de möjligheter som digitala pedagogiska transformationer ger till lärandets processer (Kjällander \& Riddersporre, 20I9; Åkerfeldt, Kjällander \& Selander, 20I8). Andra visar att digitalisering kan leda till nya begränsningar, exempelvis minskad autonomi för lärarprofessionen (Lantz-Andersson \& Säljö, 20I4). Studier av lärappar (Sjödén, 20I5) och sociala robotar (Serholt, 20I7) påvisar förekomsten av inte alltid pedagogiskt säkerställda digitala verktyg. Andra studier visar på lärarkårens blandade reaktioner och till och med motstånd visavi digitaliseringen (Grönlund, 20I4; Salavati, 2016; Tallvid, 2015). 
Arbete med MIK vid Södertörns högskola har också inspirerats av det Selwyn och Facer (20I3, s. 6, Io) kallar kritiska studier av utbildningsteknologi. Ambitionen är här att öppna "teknikens svarta låda" och att avmystifiera dominerande narrativ där "digital teknologi används som en agens för att signalera 'framtiden"' (ibid., s II). En viktig del av denna kritiska diskussion gäller det ökade inflytandet från plattformssambällets (van Dijck m.fl., 2oI8) giganter (Apple, Google, Microsoft m.fl.) och vad deras hårdvaror, mjukvaror och lärarfortbildning på sikt kan medföra för den allmänna skolan (Forsman, 20I8, 20I9; Selwyn, 20I4, 20I6; Williamson, 20I7).

\section{IMPLEMENTERING}

Innan arbetet kring MIK inom lärarutbildningen startades hade det gjorts olika försök med digitala verktyg samt flera interna utredningar kring det som då benämndes som IKT (informations- och kommunikationsteknologi). I början av 20IO-talet började begreppet digital kompetens användas. Termen kommer från EU och OECD-sammanhang och förknippas med livslångt lärande och anställningsbarhet inom ramen för så kallade 2Ist Century Skills (Hylén, 2019). Ett annat begrepp som kom upp var medie- och informationskunnighet (MIK) (Carlsson, 20I8).

Vid Södertörns högskola föll valet på MIK-termen för att komma bort från en del av de blockeringar som begreppet IKT skapat i frågor om digitalisering och lärarutbildning. Ett första initiativ i denna inriktning var en serie MIK-seminarier. Dessa pågick mellan 20I4 och 2017 och erbjöd en mix av externa och interna seminariepresentatörer. Presentationerna kunde gälla lärplattor i undervisning, en-till-en-lösningar, Flipped Classroom och lärplattformar och över till teknikfilosofiska och mediumteoretiska diskussioner om sociala robotar, lärares tekniksyn, multimodalitet och undervisningsteknologi. Målgruppen för dessa MIK-seminarier var lärarutbildare och ansvariga för Södertörns lärarprogram, från förskola till gymnasium. Under den här tiden stod Södertörns högskola också värd för två nationella MIK-konvent (Malmö, 20I4, Södertörn, 20I5) för lärarutbildare.

Under 2016 kom ett mer operativt arbete kring MIK igång i och med att det formerades en MIK-grupp. I denna ingick representanter från ämnena medieteknik, medie- och kommunikationsvetenskap, svenska och pedagogik samt medarbetare från högskolans bibliotek. Utifrån de övergripande frågorna gällande organisation och integrering av MIK i lärarutbildningen formulerades ett övergripande syfte; att utveckla ramar och strukturer för ett gemensamt och samordnat arbete med MIK på högskolans samtliga lärarutbildningar. Under de inledande mötena enades gruppen om följande arbetsbeskrivning.

- Definiera hur MIK-begreppet kan förstås på lärarutbildningen och formulera detta i ett policydokument

- Utveckla en progressionsidé för MIK och formulera lärandemål utifrån denna

- Diskutera och komma med förslag på hur progression och lärandemål kan implementeras utifrån ett konkret lärarprogram, 4-6-programmet

- Föreslå en handlingsplan för fortsatt implementering och fortsatt arbete

- Komma med förslag på en referenslista och en begreppslista som stöd för undervisande lärare

\section{ARBETE MED CENTRALA BEGREPP}

Efter många och långa diskussioner enades arbetsgruppen om att använda MIK-begreppet som en paraplyterm för tre kunskapsområden: digital kompetens, mediekunnighet och informationskunnighet. 


\section{Michael Forsman, Ingrid Forsler \& Jenny Magnusson}

Digital kompetens är det begrepp som används i Lgr II (Skolverket, 20I8) och därmed inom den svenska skolvärlden. Det anges också av EU som en av åtta centrala 2Ist Century Skills, dvs. förmågor som förväntas krävas av framtidens arbetskraft och medborgare (jfr Hylén, 2019). Digital kompetens, som också förknippas med livslångt lärande och anställningsbarhet, är ett så kallat loose concept vilket innebär att det inte finns någon entydig eller stabil definition. Snarare kan detta (liksom andra policyorienterade begrepp) användas av olika aktörer, i olika kontexter och för olika syften (Forsman, 20I8). Inte heller Skolverket (20I7) tycks ha eftersträvat en entydig definition utan pekar på ett dynamiskt och kontextbundet begrepp vars konkreta innebörd ska relateras till teknologisk förändring och till olika skolsammanhang (årskurs, ämne etc.). Skolverket relaterar även digital kompetens till entreprenörskap och kreativitet, samt till förmågan att förstå digitaliseringens påverkan på samhället. Baserat på detta enades arbetsgruppen om följande definition för digital kompetens inom Södertörns lärarutbildning: De blivande lärarnas förmåga att säkert och kritiskt tillämpa, vidareutveckla och reflektera över olika digitala undervisningsresurser på ett adekvat sätt i relation till elevernas förutsättningar (ålder etc.), skolämnens karaktär och sin professionsutveckling i möte med framtidens arbetsmarknader.

Begreppet mediekunnighet (media literacy) har rötter i mediepedagogik (1960-80-tal) gällande hur skolan kan bemöta elevernas alltmer medialiserade uppväxt. Inom denna tradition betonas bland annat förmågan att söka, hantera och kritiskt värdera och analysera medier och information i olika mediesammanhang liksom förmåga att använda medier för att själv uttrycka sig (Carlsson, 20I8). Till detta fält hör också kunskaper om samhällets medialisering och hur mediers teknologier, institutioner och logiker inverkar på skolan och på samhället i stort. På så sätt knyts lärarstudenternas mediekunnighet också till insikter om skolan som medieplats och hur olika skolämnens medieekologier inverkar på synen på kunskap och utbildning (jfr Erixon, 20I4). Mot bakgrund av detta enades arbetsgruppen om följande definition av mediekunnighet: De blivande lärarnas kunskaper om mediers samhälleliga och kulturella funktioner och logiker samt mediers betydelse i barns och ungas liv i och utanför skolan.

Begreppet informationskunnighet (information literacy) härrör från biblioteks- och arkivvärlden och avser de blivande lärarnas kunskaper om och förmåga att söka, filtrera, och kritiskt värdera samt själva producera och sprida relevant information på ett korrekt, säkert och etiskt hållbart sätt. Det handlar om att använda bibliotek, databaser, arkiv, massmedier, internetsökningar och andra resurser för att söka, välja, granska och sammanställa information på ett meningsfullt sätt som kan ligga till grund för skapande av ny kunskap (Limberg \& Folkesson, 2006; Lankshear \& Knobel, 2003). Källkritiskt tänkande och förmåga att identifiera informationsbehov hos sig själv och andra ingår också (Rivano Eckerdal \& Sundin, 20I4). Mot bakgrund av detta avser arbetsgruppen följande med informationskunnighet: De blivande lärarnas kunskaper om och förmåga att söka, filtrera och kritiskt värdera samt själva producera och sprida relevant information på ett korrekt, säkert och etiskt sätt.

Sammantaget handlar dessa tre dimensioner om lärarstudenternas förmåga att säkert och kritiskt tillämpa, vidareutveckla och reflektera kring hur olika digitala undervisningsresurser kan användas på ett adekvat sätt i relation till elevernas förutsättningar och skolämnens karaktär, inom sin professionsutveckling och i möte med framtidens arbetsmarknader. Målet är att alltså att genom konkret tillämpning och kritisk reflektion bidra till att utveckla medie- och teknikmedvetna lärare i den digitaliserade skolan och det medialiserade samhället. 


\section{ARBETE MED PROGRESSIONSMODELL OCH LÄRANDEMÅL}

Progression diskuterades i MIK-arbetsgruppen, dels med avseende på studenternas progression i sin egenskap av (lärar-)studenter på en högskola och dels med avseende på den progression som de som blivande lärare kan förvänta sig av sina elever. Progression kan förstås på olika sätt och användas både i relation till individens lärande och som egenskap hos kurser eller utbildningar (Säfström, 2017). Här avses progression som egenskap hos kurser och utbildningar, där progressionen ses som "byggstenar i en process" för att nå ett slutmål (s. 58), i det här fallet en sammansatt MIK-kompetens.

I arbetet med implementeringen av MIK-perspektiv valdes ett specifikt lärarprogram som utgångspunkt, 4-6-programmet. Arbetet i detta program ska sedan fungera som modell för andra lärarprogram. En del av implementeringsarbetet har handlat om att arbetsgruppen utvecklat en progressionsmodell för hur MIK ska integreras i olika kurser i 4-6-programmet. Denna modell tar hänsyn till flera perspektiv och är inspirerad av SOLO-taxonomin. SOLO-taxonomin ser identifiering och beskrivning som enklare processer än jämförelse och problematisering och detta var en av utgångspunkterna men arbetsgruppen har också inkluderat perspektiv på studentens lärande och på den blivande lärarens undervisning av elever. Utifrån medvetenheten om hur viktig handling är i relation till lärande har vi också strävat efter att ha perspektiv som har med användning och tillämpning att göra relativt tidigt i progressionen (jfr Säfström, 2017, s. 58). Det är dock viktigt att påpeka här att ett kritiskt förhållningssätt kan visas upp också genom praktiskt/gestaltande arbete, och att progressionsmodellen inte ska förstås som en separation av kunskapsformer där teoretisk kunskap på något sätt är överordnad. MIK-aspekter som vi identifierade som centrala utifrån de tre kunskapsområdena (digital kompetens, mediekunnighet och informationskunnighet) formulerades som lärandemål med två eller tre progressionsnivåer utifrån den generella progressionsmodell som MIK-arbetsgruppen enades om:

- Inventera/beskriva/teoretiskt grunda

- Tillämpa/praktiskt genomföra/använda

- Producera/kritiskt granska/reflektera/bedöma/problematisera

Modellen grundar sig i den teoretiska utgångspunkten där MIK består av tre olika delkomponenter där det är viktigt att inte hantera MIK som enbart en instrumentell kompetens utan även som ett kritiskt förhållningssätt. Av denna anledning finns i modellen ett användningsoch tillämpningsperspektiv och ett kritiskt och problematiserande perspektiv. I modellen görs också en åtskillnad mellan enklare/mer grundläggande och mer komplexa aktiviteter utifrån SOLO-taxonomins utgångspunkter. Aktiviteten beskriva är då mer grundläggande än aktiviteten kritisk reflektion och problematisering. Modellen bygger också på en skillnad mellan teori och praktisk användning, teoretiskt grunda kontra praktiskt genomföra. Det som inte blir lika explicit i modellen är dubbelheten där både lärarstudentens lärande är centralt och hur lärarstudenten i sin tur behöver arbeta med elevers lärande. Här kan användning sägas syfta mer på studentens användning och tillämpning mer på elevens lärande, men de ligger här inte på olika nivåer i modellen och därför behöver man särskilt beakta att båda dessa perspektiv synliggörs i lärandemålen.

Ett område som är centralt för, men inte avhängigt, digitaliseringen är multimodalitet. Som Petra Magnusson (20I4) diskuterar i sin avhandling har utvecklingen av nya medieteknologier "gjort andra teckenvärldar än den verbalspråkliga mer tillgängliga och lättare att utnyttja för meningsskapande, till följd av att produktion och distribution har blivit enklare genom de 


\section{Michael Forsman, Ingrid Forsler \& Jenny Magnusson}

digitala medierna” (s. 4I). Detta gäller såväl lärares som elevers praktiker och arbetsgruppen har i detta sammanhang kopplat multimodalitet till MIK-perspektivet digital kompetens och till det arbetsgruppen beskriver som "de blivande lärarnas förmåga att säkert och kritiskt tillämpa, vidareutveckla och reflektera över olika digitala undervisningsresurser" (jfr Godhe \& Hashemi, 2019). Progressionen när det gäller multimodalitet formulerades i fyra lärandemål utifrån fyra progressionsnivåer, där den första progressionsnivån fokuserar beskrivning och exemplifiering, medan den andra nivån fokuserar praktisk användning, den tredje nivån fokuserar bedömningar och den fjärde ett kritiskt förhållningssätt:

- beskriva och exemplifiera hur multimodalitet kan användas i olika undervisningssammanhang och med olika syften

- diskutera hur multimodalitet kan användas i undervisning och praktiskt arbeta med olika former av multimodala uttrycksformer

- bedöma elevers multimodala lärandeaktiviteter

- kritiskt värdera, välja och producera multimodala lärandeaktiviteter anpassade till elevers olika förutsättningar

I denna progression ryms alltså såäl SOLO-taxonomins tanke om enklare och mer komplexa aktiviteter som mer teoretiska utgångspunkter där både användning och kritiskt förhållningssätt ska inrymmas. På termin ett har studenterna hittills haft en föreläsning om multimodalitet och visuellt lärande under sin andra delkurs, och sedan har de under sin verksamhetsförlagda kurs fått observera hur det ser ut på deras respektive skolor som de har besökt. Utifrån föreläsning och kurslitteratur har detta sedan följts upp och diskuterats under ett seminarium där också studenterna har fătt i uppgift att göra en enkel multimodal presentation i relation till ett specifikt ämnesinnehåll. Detta motsvarar det första och det andra progressionssteget.

Ett annat exempel rör användandet av informationsresurser, vilket är relevant i en skolkontext genom att såväl lärare som elever behöver förhålla sig till den mängd olika informationsresurser som finns. Detta har med MIK-perspektivet informationskunnighet att göra, det vill säga "de blivande lärarnas kunskaper om och förmåga att söka, filtrera, och kritiskt värdera samt själva producera och sprida relevant information på ett korrekt, säkert och etiskt sätt”. När det gäller förmågan att använda informationsresurser formulerades lärandemål utifrån två progressionssteg, där det första steget fokuserar just studentens egna lärande i relation till sin roll som blivande lärare, medan det andra steget fokuserar elevens lärande och hur studenten kan planera kommande undervisning där elevens informationskunnighet kan stärkas:

- söka, kritiskt värdera och använda olika typer av informationsresurser i planeringen av undervisning

- planera undervisning som stärker elevernas informationskunnighet, med särskilt fokus mot källkritisk förmåga

Här är det just skillnaden mellan studentens lärande och undervisning för att stötta elevens lärande som motiverat de två olika progressionsstegen.

I ett tredje exempel tas ungas medievärldar upp som något lärare behöver känna till, förhålla sig till och också använda sig av. Det handlar här om MIK-perspektivet mediekunnighet, av arbetsgruppen beskrivet som "de blivande lärarnas kunskaper om mediers samhälleliga och kulturella funktioner och logiker samt mediers betydelse i barns och ungas liv i och utanför skolan". 
Progressionen formuleras här i tre steg och utgår från beskrivning, därefter analys och slutligen diskussion och problematisering:

- beskriva och diskutera barns och ungas medievärldar

- analysera barn och ungas identitetsskapande praktiker i olika medievärldar

- diskutera möjligheter och risker i barns och ungas medievärldar

Här har utgångspunkten för progressionsstegen varit olika nivåer av diskussion i allmänhet kontra diskussion kring möjligheter och risker. Det första är tänkt att vara orienterande och teoretiskt grundande medan de senare avser problematisering och ett kritiskt förhållningssätt. I lärandemålen ingår såväl ett student- och blivande lärare-perspektiv i form av teoretisk grund och diskussion på olika nivåer som ett perspektiv riktat mot förståelse för elevers görande och lärande, genom analys av barns och ungas mediepraktiker.

Trots att arbetsgruppen har formulerat en mängd lärandemål utifrån progressionsmodellen är det fortfarande bara frågan om preliminära förslag som behöver testas, modifieras och utvecklas vidare. I detta arbete har också en gemensam matris använts för att få en överblick över utbildningsprogrammet som helhet. I matrisen framgår undervisningsaktiviteter, lärandemål och relevant kurs. Genom att formulera, dokumentera och göra översikter hålls MIK-perspektivet samman och synliggörs inom hela lärarutbildningen. Det blir med matriser, formulerade lärandemål och definitioner av begrepp möjligt att presentera utgångspunkter och diskutera dessa med kollegor i olika sammanhang och forum.

\section{REFLEKTIONER OCH VÄGEN FRAMÅT}

Arbetsgruppen har hittills formulerat ett policydokument med de begreppsliga utgångspunkterna för arbetet med MIK på alla lärarprogram, utvecklat en progressionsmodell, formulerat lärandemål och föreslagit vissa lärandeaktiviteter i relation till dessa lärandemål. Detta är de första stegen i en förändringsprocess. För vidare utveckling har vissa större satsningar och aktiviteter planerats eller genomförts. Arbetsgruppen har arrangerat en heldag för alla undervisande lärare som bland annat innehöll prova-på-workshoppar kring flippade föreläsningar, programmering och maker-space. En liknande dag har getts för alla lärarstudenter. Det har också genomförts en utbildningsdag för alla studenter på lärarprogrammet för årskurs 4-6 där fokus låg helt på programmering. Vid samtliga av dessa tillfällen har det policydokument som arbetsgruppen utvecklat presenterats och forskare och föreläsare inom området har bjudits in.

Samtidigt har det uppenbarats en del ämnesmässiga spänningar gällande hur digitalisering och MIK kan eller bör förstås och vem som har ansvar för införandet av detta i lärarutbildningens kurser. En utmaning är den beställarorganisation som Södertörns högskola använder sig av och som innebär att lärarutbildningen hyr in lärarutbildare från högskolans olika ämnen, vilket ger svårigheter i fråga om kontinuitet och ansvar. Således har MIK-arbetet aktualiserat en rad frågor gällande styrning, tröghet och motstånd, begreppsvariation och olika agendor inom en organisation (jfr Grönlund, 2014).

En sådan fråga är hur man ska undvika att förändringsarbete som detta blir bundet till och beroende av en mindre grupp eldsjälar och riskerar att stanna av ifall tillräckligt många från denna grupp slutar eller får andra arbetsuppgifter. Att implementera utvecklingsarbetet i form av begreppsdefinitioner, progressionsmodeller och lärandemål har varit ett sätt att försöka undvika detta och garantera kontinuitet. Samtidigt är vi medvetna om att hur ett moment genomförs och värderas i en kurs beror mycket på de undervisande lärarna. Förutom att sprida 
modellen och matrisen från 4-6-programmet till de andra lärarprogrammen på högskolan, samtidigt som MIK fortsätter utvecklas inom 4-6, krävs det därför att samtliga kursansvariga och lärare är införstådda och engagerade.

Ett försök att nå lärarutbildarna på ett tidigt stadium och skapa en samsyn kring vad MIK är på Södertörns högskola och inom våra lärarutbildningar var den tidigare beskrivna temadagen där många av lärarutbildarna deltog. Vi hoppas att de erfarenheter som gjordes där och den fortsatta implementeringen av undervisningsupplägg som finns för 4-6-programmet på sikt kommer att genomsyra verksamheten. Detta kan dock utvärderas tidigast efter några terminer när studenterna mött MIK-moment i flera kurser och på olika nivåer, och ur ett vidare perspektiv först efter avslutad utbildning i mötet med den digitaliserade skolan.

Vi avser också att involvera studenter under pågående utbildning för att skapa en permanent och genomtänkt förändring av lärarprogrammen, vilket i sig utgör en andra utmaning. Studenter måste ges konkreta möjlighet till inflytande och eget arbete. Förutom utbildningsdagar för studenter i olika konstellationer har vi i MIK-arbetsgruppen diskuterat möjligheten att tillhandahålla digitala resurser för självstudier i att hantera olika programvaror, till exempel i form av "digital tutorials" som görs tillgängliga online, vilket gör att tiden i klassrummet kan läggas på annat än teknisk handledning.

Utöver detta kvarstår utmaningar i fråga om digitala system och mjuk- och hårdvaror. För det första måste högskolans digitala miljö fungera väl och delvis anpassas till de särskilda behov lärarutbildningen har. För det andra har skolor och studenter förväntningar på vilka programvaror och lärplattformar som en lärarutbildning borde utbilda i. Många studenter vill ha mer "hands-on-kunskaper" och känna att de behärskar specifika digitala verktyg (exempelvis olika pedagogiska appar) för att direkt kunna omsätta detta i praktik och yrkesliv. Ur lärarutbildningens perspektiv är inte detta en hållbar modell eftersom teknikutvecklingen är så snabb, samtidigt som det finns stora variationer i vilka digitala system, verktyg och läromedel som används runt om i svenska skolor. Dessutom är och bör högskolan kanske vara en mer trögrörlig organisation, även om trögheten ibland yttrar sig i ett visst motstånd från lärarutbildarnas sida då det gäller implementeringen av ny teknik. Det är viktigt att högskolan inte anpassar sin verksamhet helt till det som för tillfället efterfrågas av huvudmän eller styrs av det som den växande mångmiljardmarknaden för ed-tech för tillfället har att erbjuda och föreslår.

Vi menar att lärarutbildningen i det fortsatta arbetet med de tre förmågor som samlas under MIK bör sträva bortom förståelsen av digitala tekniker som verktyg och istället tänka mer kring medier som miljöer och infrastrukturer (jfr Peters, 20I5). Tydligast blir detta kanske i de nya utmaningar som uppstår när datordrivna teknologier introduceras i skolan. För att förbereda lärarstudenter på en skolvardag där elevdata i allt högre utsträckning används för utvärdering, personalisering och kunskapskontroll menar vi att det inte räcker att behärska enskilda programvaror. Lärarutbildningarna behöver även ta upp andra frågor som: Vilka kategorier ligger till grund för de data som samlas in? I vems intresse implementeras ny teknik i skolan? När bör jag som lärare använda digitala tekniker för bedömning, administration och kommunikation och när bör jag låta bli? (jfr Gray, Gerlitz \& Bounegru, 20I8). Med andra ord: Vad krävs av en professionell lärare för att förstå, orientera sig och ta väl underbyggda beslut i en värld där många bedömningar görs av datorer? I våra lärandemål adresseras detta genom att digital kompetens inte bara definieras som en teknisk färdighet utan också som förmågan att kunna utvärdera digitala pedagogiska hjälpmedel utifrån de kunskapsformer de prioriterar.

Samtidigt måste lärarutbildningarna våga interagera praktiskt och handgripligt med digitala tekniker och skapa tillfällen för studenter att pröva, experimentera och använda medier på nya 
sätt. Det gäller att förstå grunderna i hur programmering eller datainsamling fungerar, eller att för den delen ha kunskap om bildbehandling eller redigeringsprocesserna bakom en Wikipediaartikel. Det är också detta vi menar med att öppna den svarta lådan. Om blivande lärare och skolutvecklare inte ges möjlighet att både interagera med och kritiskt förstå och granska den digitala miljö som bäddar in dagens och framtidens skola, riskerar ed-tech-företag och plattformsgiganter att ta över utvecklingsarbetet och riktningen på den pedagogiska orienteringen inom framtidens skola (Williamsson, 20I7). Av denna anledning föregås det tidigare diskuterade målet om att kunna kritiskt granska och utvärdera digitala verktyg $\mathrm{i}$ vår progressionsmodell av ett moment i praktisk programmering och datalogiskt tänkande.

Ett kritiskt perspektiv på digitala medier i skolan (jfr Selwyn \& Facer, 20I3) som miljöer och infrastrukturer är också ett sätt att knyta ihop mediekunnighet, informationskunnighet och digital kompetens med skolans och högskolans hållbarhetsarbete. En framtida utvecklingsmöjlighet $\mathrm{i}$ arbetet som beskrivits här blir då att integrera diskussioner om digitaliseringens konsekvenser för miljö och klimat i de olika kurserna, med hjälp av särskilda lärandemål eller som ett mer övergripande perspektiv. I ambitionen att öppna den svarta lådan kan det ingå att börja fundera på vilka naturresurser som krävs för att producera de hårdvaror och den elektricitet som behövs för att driva skolans digitalisering och för att lagra och skicka stora mängder data. Detta perspektiv har ännu inte implementerats fullt ut men utgör för oss en logisk konsekvens av ett holistiskt tänkande kring skolan som mediemiljö.

Det medieekologiska perspektivet på skolans digitalisering grundar sig också i ett historiserande tänkande och en strävan efter balans mellan olika medieteknologier (Postman, 1992). Detta synsätt har genomsyrat hela detta projekt genom att I) hela tiden betona att även invanda aspekter av skolmiljön, som böcker eller whiteboardtavlor, också utgör medier som prioriterar vissa typer av tänkande och handlande och att 2) betona att digital kompetens också handlar om att veta när man ska välja bort digital teknik. Dessa utgångspunkter innebär inte bara ett problematiserande av de mest teknikdeterministiska och presentistiska beskrivningarna av skolans digitalisering utan utgör också ett sätt att visa hur olika synsätt på kunskap och skolans uppdrag knyts till de medier och teknologier som används i dagens skola.

\section{SLUTORD}

I den här artikeln har vi beskrivit och diskuterat hur lärarutbildningarna på Södertörns högskola har tagit sig an utmaningen med att förstärka digital kompetens, mediekunnighet och informationskunnighet. Vi har försökt visa på vilka sätt implementering, organisation och integration av MIK i olika kurser och lärarprogram kan läggas upp. Vi har förordat en progressionsmodell som bygger på konkretiseringar av lärandemål och uppgifter för lärarstudenterna. Vi lyfter vidare fram vikten av att använda begrepp som kan öppna för pluralistiska sätt att tänka kring skolans digitalisering, där vi har använt MIK som ett paraplybegrepp för tre olika former av kompetenser som konkretiseras genom progressionsmodellen och olika lärandemål och övningar. Vår utgångspunkt och vårt mål har varit att möjliggöra ett breddat sätt att tänka kring digitaliseringen och dess konsekvenser i förhållande till skolan och lärarutbildningen i stort. Efter detta inledande arbete återstår att driva frågorna vidare på ett sätt som kan sammanlänka våra olika lärarprogram. I detta är samverkan med VFU-skolor och kommuner en viktig pusselbit. Studenterna är en resurs och tvärvetenskapliga möten mellan olika högskoleämnen en förutsättning. Andra pusselbitar är forskning och erfarenhetsutbyte med olika lärosäten som bedriver lärarutbildning. 


\section{Michael Forsman, Ingrid Forsler \& Jenny Magnusson}

En av de stora utmaningarna för landets lärarutbildningar är att hänga med i den accelererande digitaliseringen som teknisk process och låta den inverka på hur lärarutbildningen organiseras och genomförs, såväl i fråga om konkreta färdigheter som kritiska perspektiv. Den digitaliserade skolan medför en förändrad infrastruktur och medieekologi för kunskapsproduktion, undervisning och lärande. Digitaliseringen betecknar också en epokgörande samhällelig transformation i fråga om ekonomi, arbete, skola, minne, övervakning, fritid, hälsa, familj, offentlighet, demokrati och identitetsarbete samtidigt som den utgör en dominerande ideologi som bygger på antaganden om att "nya medier" skapar social förändring och förbättrad skola. För att nyansera denna bild menar vi att det är viktigt för blivande lärare att förstå digitaliseringen både ur ett historiskt och ett ekologiskt perspektiv. I utvecklingsarbetet som beskrivs här har vi tagit de första stegen $\mathrm{i}$ en sådan process genom att förorda kritiska och explorativa förhållningssätt till digital teknik och att betona mediekunnighet, informationskunnighet och digital kompetens som komplexa kunskapsfält med möjlighet till progression snarare än som färdigheter. Vi hoppas kunna utveckla dessa perspektiv framöver med ökat fokus på hållbar utveckling och ett miljömedvetet förhållande till teknikutveckling och implementering.

I och med den ökande trenden mot automatiserat och personaliserat lärande uppstår också frågor om lärarprofessionens särart och lärarutbildningarnas autonomi i förhållande till styrningsrationaliteten bakom skolans digitalisering. Vi menar att det är viktigt att utveckla ett professionellt omdöme och förmågan att välja "rätt" teknik i olika pedagogiska sammanhang. Det kan inte, och ska inte, vara lärarutbildningens uppdrag att utbilda blivande lärare till oreflekterad tillämpning av programvaror och plattformar. I den modell som Södertörns högskola hittills har använt i sitt inre arbete med den teknik- och mediemedvetna läraren i den digitaliserade skolan och det medialiserade samhället har vi försökt kombinera praktiska färdigheter i informationssökning och teknikanvändning med kritiska perspektiv på medier och medieutveckling. Vi har valt att arbeta på bred och generell front med dokument, inspiration och implementering men har inledningsvis gjort det inom ett specifikt lärarprogram där vi skapat matriser och modeller. Förhoppningsvis ges vi resurser och mandat att driva denna utveckling vidare.

\section{FÖRFATTARPRESENTATION}

Michael Forsman är docent i medie- och kommunikationsvetenskap vid Södertörns högskola, meriterad lärare, och har arbetat inom högskolans lärarutbildning sedan sent 1990-tal. Han har forskat om public service, barn, ungdom, medier och populärkultur. På senare år har hans forskningsintresse riktats alltmer mot frågor om medier och skola, medieundervisning, digital kompetens samt medie- och informationskunnighet (MIK).

Ingrid Forsler har disputerat i medie- och kommunikationsvetenskap med en avhandling om hur bildlärare förhåller sig till och förhandlar skolans och bildämnets mediemiljöer. Hon undervisar på Södertörns högskola samt på Beckmans designhögskola bland annat i medier och visuell kultur samt på lärarutbildningen. Hennes forskningsintressen inkluderar föreställningar om medier i utbildning samt infrastrukturella perspektiv.

Jenny Magnusson är docent i svenska och excellent lärare vid Södertörns högskola. Hon arbetar som programansvarig för ett av grundlärarprogrammen, och undervisar framförallt på uppsatskurser och på kurser i akademiskt skrivande. Hennes forskningsinriktning rör akademiskt skrivande och hon har forskat om bland annat handledning och skrivundervisning. 


\section{REFERENSER}

Biesta, G. (2011). God utbildning i mätningens tidevarv. (1. uppl.) Stockholm: Liber.

Breiter, A. (2014). Schools as mediatized worlds from a cross-cultural perspective. I A. Hepp \& F. Krotz (red.), Mediatized worlds: culture and society in a media age. Basingstoke: Palgrave Macmillan.

Carlsson, U. (red.) (2018). Medie- och informationskunnighet (MIK) i den digitala tidsaildern: en demokratifråga: kartläggning, analys, reflektioner. Göteborg: Nordicom.

Erixon, P.-O. (red.) (2014). Skolämnen i digital förändring: en medieekologisk undersökning. Lund: Studentlitteratur.

Forsler, I. (2020). Enabling media: Infrastructures, imaginaries and cultural techniques in Swedish and Estonian visual arts education. Diss. Huddinge: Södertörns högskola.

Forsman, M. (2018). Digital competence and the future media citizen: A preliminary conceptual analysis. The Journal of Media Literacy 65 (1-2). Madison: The National Telemedia Council.

Forsman, M. (2019). Framtiden är redan här. Om plattformiseringen av skolan och fostran av framtidens mediemedborgare. I J. Andersson-Schwarz \& S. Larsson (red.), Plattformssambället. Den digitala utvecklingens politik, innovation och reglering. Stockholm: Fores.

Godhe, A.-L. \& Hashemi, S. (2019) (red.). Digital kompetens för lärare. Malmö: Gleerups.

Gray, J., Gerlitz, C. \& Bounegru, L. (2018). Data infrastructure literacy. Big Data \& Society. https://doi. org/10.1177/2053951718786316.

Grönlund, Å. (2014). Att förändra skolan med teknik: bortom "en dator per elev". Örebro: Örebro universitet

Grönlund, Å. \& Wiklund, M. (2018). Det digitala lärandets möjligheter: att leda den digitala skolan. Malmö: Gleerups.

Hylén, J. (2011). Digitaliseringen av skolan (2. rev. uppl.). Lund: Studentlitteratur.

Hylén, J. (2019). Framtidens arbetsmarknad - framtidens skola. Lund: Studentlitteratur.

Jarke, J. \& Breiter, A. (2019). Editorial: the datafication of education. Learning, Media and Technology, 44:1.

Kjällander, S. \& Riddersporre, B. (red.) (2019). Digitalisering i forskolan: på vetenskaplig grund (1. uppl.). Stockholm: Natur \& Kultur.

Krotz, F. (2014). Mediatization as a mover in modernity: social and cultural change in the context of media change. I K. Lundby (red.), Mediatization of communication. Berlin: De Gruyter Mouton.

Lankshear, C. \& Knobel, M. (2003). New literacies: changing knowledge and classroom learning. Buckingham: Society for Research into Higher Education \& Open University Press.

Lantz-Andersson, A. \& Säljö, R. (red.) (2014). Lärare i den uppkopplade skolan (1. uppl.). Malmö: Gleerups.

Limberg, L. \& Folkesson, L. (2006). Undervisning i informationssökning: slutrapport frän projektet Informationssökning, didaktik och lärande (IDOL). Borås: Valfrid.

Magnusson, P. (2014). Meningsskapandets möjligheter: multimodal teoribildning och multiliteracies i skolan. Diss. Malmö: Malmö högskola.

McLuhan, M. (1969). Gutenberg-galaxen: den typografiska människans uppkomst. Stockholm: PAN/ Norstedt.

McLuhan, M. (1987). Understanding media: the extensions of man. London: Ark.

Peters, J. D. (2015). The marvelous clouds: toward a philosophy of elemental media. Chicago: The University of Chicago Press.

Postman, N. (1992). Technopoly: the surrender of culture to technology. New York: Knopf.

Rivano Eckerdal, J. \& Sundin, O. (red.) (2014). Medie- och informationskunnighet i en biblioteks- och informationsvetenskaplig belysning. Stockholm: Svensk biblioteksförening.

Salavati, S. (2016). Use of digital technologies in education: the complexity of teachers' everyday practice. Diss. Växjö: Linneuniversitet.

Selwyn, N. (2014). Distrusting educational technology: critical questions for changing times. New York: Routledge.

Selwyn, N. (2016). Is Technology Good for Education? Cambridge: Polity Press. 


\section{Michael Forsman, Ingrid Forsler \& Jenny Magnusson}

Selwyn, N. \& Facer, K. (2013). Introduction: the need for a politics of education and technology. I N. Selwyn \& K. Facer (red.), The politics of education and technology. Conflicts, Controversies, and Connections. Basingstoke: Palgrave Macmillan.

Serholt, S. (2017). Child-robot interaction in education. Diss. Göteborg: Göteborgs universitet.

Sjödén, B. (2015). What makes good educational software? Diss. Lund: Lunds Universitet.

Skolverket. (2017). Få syn på digitaliseringen på grundskolenivå. Ett kommentarmaterial till läroplanerna för forskoleklass, fritidshem och grundutbildning. Stockholm: Skolverket.

Skolverket. (2018). Läroplan för grundskolan, förskoleklassen och fritidshemmet 2011: reviderad 2018. Stockholm: Skolverket.

Statens medieråd. (2019). MIK för framtida lärare och bibliotekarier. Hämtad 2019-11-25 från https://statensmedierad.se/

Säfström, A. I. (2017). Progression i högre utbildning, Högre utbildning 7(1).

Tallvid, M. (2015). 1:1 i klassrummet: analyser av en pedagogisk praktik i förändring. Diss. Göteborg: Göteborgs universitet.

van Dijck, J., Poell, T. \& Waal, M. D. (2018). The platform society: public values in a connective world. New York: Oxford University Press.

Williamson, B. (2017). Big data in education: the digital future of learning, policy and practice. Los Angeles: SAGE.

Åkerfeldt, A., Kjällander, S. \& Selander, S. (2018). Programmering: introduktion till digital kompetens i grundskolan. Stockholm: Liber. 